\title{
Wake-active neurons across aging and neurodegeneration: a potential role for sleep disturbances in promoting disease
}

\author{
Anna L Stern and Nirinjini Naidoo*
}

\begin{abstract}
Sleep/wake disturbance is a feature of almost all common age-related neurodegenerative diseases. Although the reason for this is unknown, it is likely that this inability to maintain sleep and wake states is in large part due to declines in the number and function of wake-active neurons, populations of cells that fire only during waking and are silent during sleep. Consistent with this, many of the brain regions that are most susceptible to neurodegeneration are those that are necessary for wake maintenance and alertness. In the present review, these wake-active populations are systematically assessed in terms of their observed pathology across aging and several neurodegenerative diseases, with implications for future research relating sleep and wake disturbances to aging and age-related neurodegeneration.
\end{abstract}

Keywords: Aging; Neurodegeneration; Sleep; Daytime sleepiness; Fragmentation

\section{Introduction}

Over the course of healthy human aging, many aspects of sleep are significantly altered. Some of these alterations include decreased slow wave sleep (stages 3 and 4), changes in delta power, decreased homeostatic sleep responses, phase shifts, increased instances of sleepdisordered breathing, periodic limb movements, and sleep and wake fragmentation (Bliwise 1993)(Roenneberg et al. 2004)(Ohayon et al. 2004)(Foley et al. 2007)(Conte et al. 2014). Sleep fragmentation refers to frequent nocturnal awakenings, and wake fragmentation refers to an inability to maintain wakefulness throughout the day often leading to increased daytime napping. Increased instances of napping among the elderly are often attributed to excessive daytime sleepiness (EDS), which affects approximately $18 \%$ of cognitively normal adults aged 65-85 (Jaussent et al. 2012) and is the number one sleeprelated predictive factor of a poor quality of life in this population (Reid et al. 2006). Age, independent of overall health, is the third most significant risk factor for EDS (Bixler et al. 2005), but EDS is also an even more prominent feature of almost every common age-related

\footnotetext{
* Correspondence: naidoo@mail.med.upenn.edu

Center for Sleep and Circadian Neurobiology, Perelman School of Medicine, University of Pennsylvania, Philadelphia, USA
}

neurodegenerative disease including Alzheimer's disease (AD) (Merlino et al. 2010)(Bonanni et al. 2005), Parkinson's disease (PD) (Arnulf and Leu-Semenescu 2009), Amyotrophic Lateral Sclerosis (ALS) (Lo Coco et al. 2011), and Frontotemporal Lobar Degeneration (FTLD) (Bonakis et al. 2014). Depending on the disease in question, varying theories exist to explain the emergence of EDS as a result of the underlying pathology - this is a complex task, given that the causes of EDS emergence in both healthy aging and disease are likely to be multifactorial and include fatigue, boredom, or other psychological factors (Bliwise 1993). However, one intriguing possibility is that a unifying histological feature of neurodegenerative diseases, the disruption and loss of wake-active neurons, is triggered or exacerbated by sleep fragmentation and in turn contributes to the observed daytime sleepiness. This is consistent with a model in which the disrupted sleep that is characteristic of normal aging contributes to the increased likelihood of disease onset in the elderly population.

Wake-active neurons are neurons that fire action potentials with high frequency during waking and very low frequency during sleep; these cells include orexinergic (de Lecea and Huerta 2014), noradrenergic (González and Aston-Jones 2006), cholinergic (Platt and Riedel 2011), histaminergic (Huang et al. 2001), serotonergic (Monti 2011), 
and dopaminergic ( $\mathrm{Lu}$ et al. 2006) populations (Figure 1). Each of these cell groups is known to be critical for maintenance of consolidated and attentive wakefulness, and each is affected to varying degrees across normal aging and neurodegenerative disease. In this review we aim to synthesize a wide body of literature on the changes observed in these wake-active cells in aging and disease (summarized in Table 1), providing evidence that these changes may both contribute to disease progression and be exacerbated by sleep disturbances.

\section{Sleep phenotypes across neurodegenerative disease} Alzheimer's disease

Alzheimer's Disease (AD) is the most common agerelated neurodegenerative disease in the world, and it is the leading cause of dementia (Peter-Derex et al. 2014). Brains of AD patients accumulate aggregates of $\beta$-amyloid and hyperphosphorylated tau called plaques and neurofibrillary tangles (NFTs), respectively (Bloom 2014). This pathology is accompanied by widespread neuronal loss, particularly in cortical and subcortical regions involved with cognition and memory (Bouras et al. 1994). Up to $45 \%$ of Alzheimer's patients suffer from at least one sleep disorder (Peter-Derex et al. 2014). Nocturnal awakenings and EDS are the most common of these, with one study finding that the average AD patient gets over $14 \%$ of their total sleep during the daytime (Vitiello et al. 1992). The extent to which sleep is fragmented is correlated with severity of dementia (Pat-Horenczyk et al. 1998), and it is one of the leading causes of institutionalization among patients (Bonanni et al. 2005). Although sleep consolidation does decline as the disease progresses and is often considered to be a consequence of disease, there is retrospective evidence that frequent daytime napping in healthy elderly subjects is predictive of a later diagnosis of $\mathrm{AD}$ in those carrying the ApoE- $\varepsilon 4$ allele, which confers genetic risk of AD (Lim et al. 2013b). This could indicate that either EDS itself or loss of integrity of wake-active neurons is a contributing factor in the onset of AD.

\section{Parkinson's disease}

Parkinson's Disease (PD), the second most common neurodegenerative disease, is characterized primarily by a loss of movement and postural control resulting from decreased dopaminergic neurons in the area substantia nigra (SN). Degeneration in $\mathrm{SN}$ and other areas is accompanied by accumulation of Lewy Bodies, intracellular aggregates of $\alpha$-synuclein (Langston et al. 2013). Almost all PD patients experience diminished sleep quality of some kind (Lima 2013), and the namesake of the disease James Parkinson even noted in his first published description of symptoms that "...the sleep becomes much disturbed” (Parkinson 2002). PD patients are awake for an average of $30-40 \%$ of the night (De Cock et al. 2008), and over a third of patients experience EDS during the day (Arnulf and Leu-Semenescu 2009) this is reflected by a $225 \%$ increase in time spent napping by PD patients as compared with age-matched controls (Bolitho et al. 2013). In one study, elderly subjects with EDS had more than three-fold higher likelihood of receiving a future diagnosis of PD (Abbott et al. 2005), indicating that disturbed sleep/wake may be a contributing factor rather than a consequence of disease.

PD also has high comorbidity with Rapid Eye Movement Sleep Behavior Disorder (RBD) (Gong et al. 2014), a parasomnia characterized by the loss of normal paralysis during

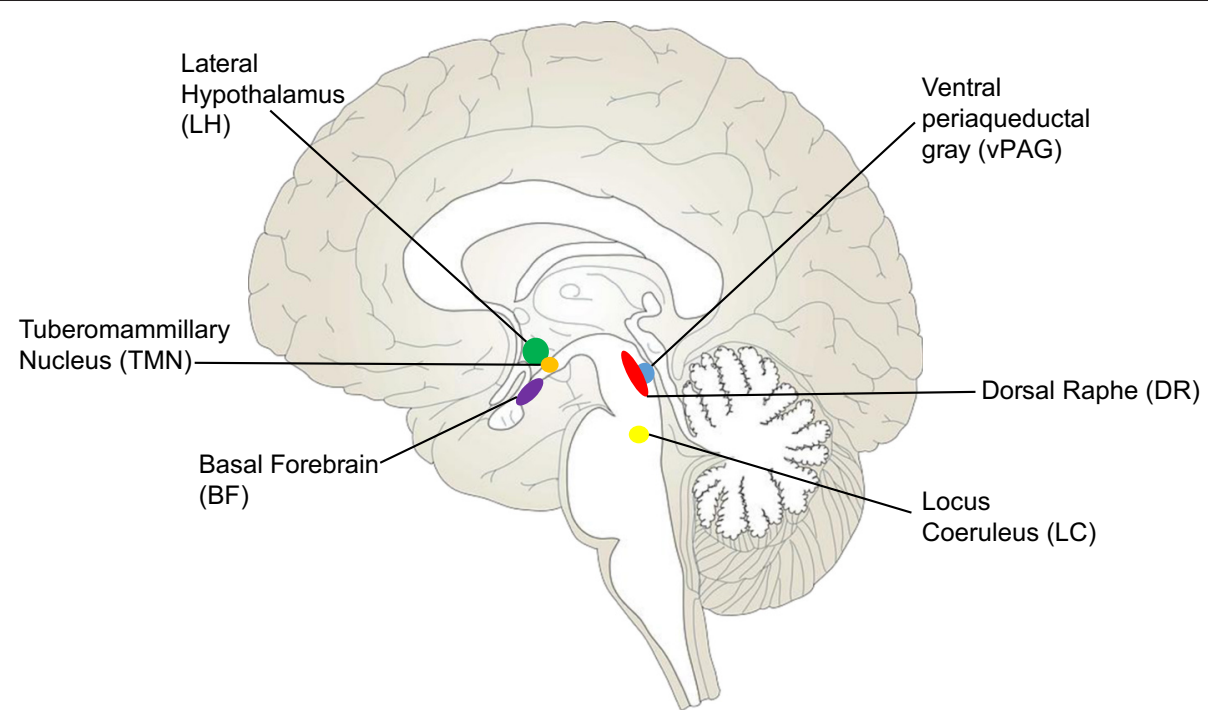

Figure 1 Midsagittal human brain section showing localization of wake-active brain regions. 
Table 1 Changes in wake-active neuronal populations across aging and neurodegenerative disease

\begin{tabular}{|c|c|c|c|c|c|c|}
\hline Cell type & Region & Aging & Alzheimer's (AD) & $\begin{array}{l}\text { Parkinson's/Dementia with } \\
\text { Lewy Bodies (PD/DLB) }\end{array}$ & $\begin{array}{l}\text { Amyotrophic Lateral } \\
\text { Sclerosis (ALS) }\end{array}$ & $\begin{array}{l}\text { Frontotemporal Lobar } \\
\text { Degeneration (FTLD) }\end{array}$ \\
\hline \multirow[t]{4}{*}{ Orexinergic } & \multirow[t]{4}{*}{ Lateral Hypothalamus (LH) } & $\begin{array}{l}\text {-Cell loss(Kessler et al. 2011) } \\
\text { (Brownell and Conti 2010) }\end{array}$ & •Cell loss (Fronczek et al. 2012) & $\begin{array}{l}\text {-Cell loss (Thannickal et al. 2007) } \\
\text { (Lessig et al. 2010) }\end{array}$ & & \multirow{4}{*}{$\begin{array}{l}\text {-Decreased plasma orexin } \\
\text { concentration (Çoban } \\
\text { et al. 2013) }\end{array}$} \\
\hline & & \multirow{3}{*}{$\begin{array}{l}\text {-Loss of fibers (Stanley and } \\
\text { Fadel 2012)(Downs et al. 2007) } \\
\text { (Zhang et al. 2005) } \\
\text {-Decreased responsiveness } \\
\text { to orexin in projection areas } \\
\text { (Stanley and Fadel 2012) }\end{array}$} & \multirow{3}{*}{$\begin{array}{l}\text {-Decreased CSF orexin } \\
\text { concentration (Fronczek } \\
\text { et al. 2012) }\end{array}$} & $\begin{array}{l}\text {-Lewy Bodies (Fronczek } \\
\text { et al. 2007) }\end{array}$ & & \\
\hline & & & & -Decreased CSF orexin & & \\
\hline & & & & $\begin{array}{l}\text { concentration in DLB } \\
\text { (Wennström et al. 2012) }\end{array}$ & & \\
\hline \multirow[t]{3}{*}{ Noradrenergic } & \multirow[t]{3}{*}{ Locus Coeruleus (LC) } & $\begin{array}{l}\text {-Decreased noradrenaline } \\
\text { reuptake at terminals } \\
\text { (Shores et al. 1999)(Zhu } \\
\text { et al. 2005)(Shirokawa } \\
\text { et al. 2003) }\end{array}$ & -Cell loss (Brunnström et al. 2011) & -Cell loss (Brunnström et al. 2011) & $\begin{array}{l}\text {-Loss of neuron pigmentation } \\
\text { (Hoogendijk et al. 1995) }\end{array}$ & \multirow[t]{3}{*}{$\begin{array}{l}\text {-Cell loss (Brunnström } \\
\text { et al. 2011) }\end{array}$} \\
\hline & & $\begin{array}{l}\text {-Decreased DBH } \\
\text { (Zhu et al. 2005) }\end{array}$ & •NFTs (Grudzien et al. 2007) & •Lewy Bodies (Seidel et al. 2014) & $\begin{array}{l}\text {-Intracellular inclusion bodies } \\
\text { (Iwanaga et al. 1997) }\end{array}$ & \\
\hline & & $\begin{array}{l}\text {-Increased CHOP } \\
\text { (Naidoo et al. 2011) }\end{array}$ & & & & \\
\hline \multirow[t]{3}{*}{ Cholinergic } & \multirow[t]{3}{*}{$\begin{array}{l}\text { Nucleus Basalis of } \\
\text { Meynert (NBM) }\end{array}$} & $\begin{array}{l}\text {-Cell loss (Wolf et al. 2014) } \\
\text { (Grothe et al. 2012) }\end{array}$ & ·Cell loss (Rogers et al. 1985) & $\begin{array}{l}\text {-Cell loss (Rogers et al. 1985) } \\
\text { (Grothe et al. 2014)(Iranzo } \\
\text { et al. 2014) }\end{array}$ & \multirow[t]{3}{*}{$\begin{array}{l}\text {-Intracellular inclusion bodies } \\
\text { (Matsuoka et al. 2011) }\end{array}$} & \\
\hline & & $\begin{array}{l}\text {-Decreased nicotinic receptor } \\
\text { expression in cortex } \\
\text { (Nordberg et al. 1992) } \\
\text { (Uchida et al. 2013) }\end{array}$ & $\begin{array}{l}\text {-NFTs (Rogers et al. 1985) } \\
\text { (Iraizoz et al. 1999) }\end{array}$ & •Lewy Bodies (Rogers et al. 1985) & & \\
\hline & & $\begin{array}{l}\text {-Altered AMPA receptor } \\
\text { expression(Ikonomovic } \\
\text { et al. 2000) }\end{array}$ & & & & \\
\hline \multirow[t]{3}{*}{ Histaminergic } & \multirow[t]{3}{*}{$\begin{array}{l}\text { Tuberomammillary } \\
\text { Nucleus (TMN) }\end{array}$} & $\begin{array}{l}\text {-Elevated levels of CSF } \\
\text { histamine metabolites } \\
\text { (Prell et al. 1988) }\end{array}$ & $\begin{array}{l}\text {-Cell loss (Nakamura et al. 1993) } \\
\text { (Shan et al. 2012a) }\end{array}$ & •Lewy Bodies (Shan et al. 2012b) & & \\
\hline & & \multirow{2}{*}{$\begin{array}{l}\text { - Decreased binding of } \\
\text { cortex histamine receptors } \\
\text { (Yanai et al. 1992) }\end{array}$} & -NFTs (Nakamura et al. 1993) & \multirow{2}{*}{$\begin{array}{l}\text { - Increased density of } \\
\text { histaminergic fibers in SN } \\
\text { (Anichtchik et al. 2000) }\end{array}$} & & \\
\hline & & & $\begin{array}{l}\text {-Regional alterations in HDC } \\
\text { expression (Shan et al. 2012a) }\end{array}$ & & & \\
\hline \multirow[t]{4}{*}{ Serotonergic } & \multirow[t]{4}{*}{ Dorsal Raphe (DR) } & \multirow{4}{*}{$\begin{array}{l}\text {-Region-specific alterations } \\
\text { in 5-HT receptor expression } \\
\text { (Rodríguez et al. 2012) } \\
\text { (Marcusson et al. 1984) }\end{array}$} & •Cell loss (Chen et al. 2000) & •Cell loss (Halliday et al. 1990) & \multirow{3}{*}{$\begin{array}{l}\text {-Decreased CSF levels of 5-HT } \\
\text { precursor tryptophan } \\
\text { (Monaco et al. 1979) }\end{array}$} & $\begin{array}{l}\text {-Cell loss (Yang and } \\
\text { Schmitt 2001) }\end{array}$ \\
\hline & & & -NFTs (Chen et al. 2000) & •Lewy Bodies (Seidel et al. 2014) & & \multirow{3}{*}{$\begin{array}{l}\text {-Reduced 5-HT1A and } \\
5 \text {-HT2A receptor } \\
\text { expression in cortex } \\
\text { (Bowen et al. 2008) }\end{array}$} \\
\hline & & & & •Decreased CSF 5-HT & & \\
\hline & & & $\begin{array}{l}\text {-Decreased CSF 5-HT } \\
\text { concentration(Tohgi et al. 1992) }\end{array}$ & concentration (Tohgi et al. 1993) & $\begin{array}{l}\text { Decreased 5-HT receptor } \\
\text { expression in cortex } \\
\text { (Turner et al. 2005) }\end{array}$ & \\
\hline
\end{tabular}


Table 1 Changes in wake-active neuronal populations across aging and neurodegenerative disease (Continued)

\begin{tabular}{|c|c|c|c|c|}
\hline & & $\begin{array}{l}\text {-Reduced SERT expression } \\
\text { (Rodríguez et al. 2012) }\end{array}$ & \multirow{2}{*}{$\begin{array}{l}\text {-Decreased 5-HT receptor } \\
\text { expression in cortex } \\
\text { (Lai et al. 2005) }\end{array}$} & \multirow{2}{*}{$\begin{array}{l}\text {-Reduced 5-HT signaling } \\
\text { throughout brain } \\
\text { (Politis et al. 2012) }\end{array}$} \\
\hline & & $\begin{array}{l}\text {-Decreased 5-HT fiber density } \\
\text { and aberrant morphology } \\
\text { (van Luijtelaar et al. 1988) }\end{array}$ & & \\
\hline \multirow[t]{3}{*}{ Dopaminergic } & \multirow{3}{*}{$\begin{array}{l}\text { Ventral Periaqueductal } \\
\text { Gray (vPAG) }\end{array}$} & & \multirow[t]{3}{*}{ •NFTs (Parvizi et al. 2000) } & ·Cell loss (Benarroch et al. 2009) \\
\hline & & & & $\begin{array}{l}\text {-Lewy Bodies (Seidel et al. 2014) } \\
\text { (Benarroch et al. 2009) }\end{array}$ \\
\hline & & & & $\begin{array}{l}\text {-Increased rates of dopamine } \\
\text { metabolism (Kumakura et al. 2010) }\end{array}$ \\
\hline
\end{tabular}


rapid eye movement (REM) sleep, causing patients to physically act out their dreams. Although the pathophysiology of this disorder is not well understood, animal studies and post mortem analysis reveal a likely role for the breakdown of pontine brain areas involved in regulating sleep cycles (Boeve et al. 2007). One study found that over $56 \%$ of PD patients met the criteria for RBD diagnosis (Gong et al. 2014), and idiopathic RBD is also a very reliable predictor of later PD development. A recent update on a ten year longitudinal study reported that over $80 \%$ of RBD patients assessed, who showed no other signs of neurodegenerative disease at the time, received an eventual diagnosis of PD or other synucleinopathies such as Dementia with Lewy Bodies (DLB) (Schenck et al. 2013). The strong predictive value of RBD, like EDS, indicates a possible role for sleep disruption in PD onset.

\section{Amyotrophic lateral sclerosis}

In patients with Amyotrophic Lateral Sclerosis (ALS), degeneration of lower motor neurons leads to muscle weakness, paralysis, and eventual death (Rowland 2010). Up to $50 \%$ of these patients report difficulty staying asleep at night, indicating that their sleep is fragmented (Lo Coco et al. 2011). In ALS in particular, EDS is often referred to more broadly as fatigue, which affects 40$80 \%$ of patients and is strongly correlated with both disease severity and depression (Lo Coco and La Bella 2012). It is unclear in ALS to what extent fatigue is a result of poor sleep quality or a direct consequence of motor neuron degeneration, but evidence suggests that sleep complaints are highly correlated with degree of sleepiness (Lo Coco and La Bella 2012), suggesting that sleep plays a role.

\section{Frontotemporal lobar degeneration}

Frontotemporal Lobar Degeneration (FTLD), a broad term encompassing a wide range of pathologies that all involve degeneration of the frontotemporal region, accounts for 10\% of all instances of dementia (Karageorgiou and Miller 2014). Circadian rhythms are severely disrupted in FTLD patients (Anderson et al. 2009), and one study found that $64 \%$ of these patients suffer from EDS (Guarnieri et al. 2012). Recently, physicians observed that FTLD is characterized by even more severe sleep symptoms than $\mathrm{AD}$, and that the onset of symptoms occurs very rapidly during the course of disease (Bonakis et al. 2014).

\section{Wake-active neuronal pathology across aging and neurodegenerative disease}

Given the surprising consistency of sleep and wake disturbances, particularly EDS, across normal aging and various neurodegenerative diseases, a careful consideration of the potential role played by wake-active neurons in disease onset and progression is warranted. Consistent with sleep symptoms, all wake-active populations indeed undergo drastic changes over the course of aging, which may be both a cause and consequence of declining sleep quality.

\section{Orexinergic neurons of lateral hypothalamus}

A small population of cells in the lateral hypothalamus (LH) releases the neuropeptides orexin-A/hypocretin-1 and orexin-B/hypocretin-2, which coordinate wakefulness and alertness through direct communication with other wake active brain areas including locus coeruleus (LC), tuberomammillary nucleus (TMN), dorsal raphe nucleus (DRN), and ventral periaqueductal gray (vPAG) (de Lecea et al. 1998)(Peyron et al. 1998). Loss of orexinergic neurons in both humans (Thannickal et al. 2000) and animals (Chemelli et al. 1999)(Lin et al. 1999) results in a narcoleptic phenotype characterized by an inability to maintain wakefulness. Optogenetic stimulation of these neurons increases the probability of a transition from sleep to wake (Adamantidis et al. 2007), and their silencing induces sleep (Tsunematsu et al. 2011).

Consistent with a loss of wake consolidation with aging (Foley et al. 2007), substantially decreased numbers of orexin neurons have been observed in aged rats (Kessler et al. 2011) and mice (Brownell and Conti 2010), and the remaining neurons have decreased signs of activation following sleep deprivation (Naidoo et al. 2011). Moreover, orexin signaling in downstream wakeactive regions is diminished in several animal models. One group of researchers found that in aged rats, orexinergic fibers projecting to hippocampus are decreased in correlation with blunted cholinergic release in response to orexin (Stanley and Fadel 2012). Innervation of LC by orexinergic projections is decreased as well in aged rhesus macaques (Downs et al. 2007), and similar data were obtained in the basal forebrain of guinea pigs (Zhang et al. 2005). Considered together, these studies indicate that the orexin system undergoes widespread changes in both size and functionality over the course of aging, which is likely to contribute to EDS in the elderly.

In addition to changes in orexinergic function affecting sleep, decreases in sleep may in turn affect the orexin system. Chronic sleep fragmentation, for instance, decreases activation of orexinergic neurons in response to hypercapnia and decrease orexinergic projections to the cingulate cortex ( $\mathrm{Li}$ et al. 2013). Furthermore, acute sleep deprivation causes both an increased sensitivity of orexinergic neurons to the inhibitory neurotransmitter GABA (Matsuki et al. 2014) and a switch from excitation to inhibition in response to noradrenergic signaling (Grivel et al. 2005). One recent study found that when mice were deprived of sleep for 12 hours a day over 7 days, $24 \%$ of orexinergic cells in lateral hypothalamus 
were lost (Obukuro et al. 2013). This neuronal loss was dependent on S-linked nitrosylation of the critical foldase protein disulfide isomerase (PDI), and much evidence suggests that this particular protein modification plays a critical role in neurodegenerative diseases associated with protein misfolding (Uehara et al. 2006) (Halloran et al. 2013). Thus, one possibility is that sleep loss exacerbates the age-related changes in orexinergic neurons through protein dyshomeostasis, eventually leading to the development of a cellular environment that is highly susceptible to neurodegeneration (Brown and Naidoo 2012)(Roussel et al. 2013). Consistent with this, $\mathrm{AD}, \mathrm{PD}$, and DLB patients have decreased orexin cell numbers compared with age-matched controls (Fronczek et al. 2012)(Thannickal et al. 2007)(Lessig et al. 2010), and FTLD patients have decreased levels of orexin-A (Çoban et al. 2013).

\section{Noradrenergic neurons of locus coeruleus}

The LC serves a wide range of functions relating to autonomic activity, stress, learning, and arousal. The area sends dense noradrenergic projections throughout the cortex and other brain regions, including excitatory inputs to wake-active nuclei and inhibitory inputs to sleep-promoting centers such as the ventrolateral preoptic area (VLPO) (Samuels and Szabadi 2008). Locus coeruleus neurons are active during wake, particularly alert wakefulness, and are silent during sleep (Takahashi et al. 2010). Recently, the role of LC in modulating sleep-wake state was shown using optogenetic manipulations; in these experiments, stimulating noradrenergic LC neurons caused a transition from sleep to wakefulness, while silencing the same population induced sleep (Carter et al. 2010).

It has become clear over the past two decades that LC neuronal number is preserved in healthy aging (Mouton et al. 1994)(Ohm et al. 1997). However, data from both humans and animals indicate that the connectivity, expression patterns, and function of these neurons are altered over time. In humans, LC neuromelanin content increases in middle age and decreases in the elderly, which may affect susceptibility of neurons to oxidative insults (Shibata et al. 2006). Several studies in rats have demonstrated that over the course of aging, norepinephrine reuptake at axon terminals is decreased in cortex, along with decreased levels of norepinephrine transporter (NET) mRNA (Shores et al. 1999)(Zhu et al. 2005) (Shirokawa et al. 2003). Levels of mRNA encoding dopamine $\beta$-hydroxylase (DBH), the enzyme catalyzing the conversion of dopamine to norepinephrine, also decline in LC with age (Zhu et al. 2005). In LC of aged mice, expression of the pro-apoptotic factor C/EBP homologous protein (CHOP), which promotes cell death in response to protein dyshomeostasis, is dramatically increased (Naidoo et al. 2011).
Similarly to the case of orexinergic neurons, evidence in animals suggests that LC is highly susceptible to sleep disturbances. In cats, REM sleep deprivation during postnatal day 42-49 causes over half of LC neurons to be lost, in addition to an overall decrease in size of remaining cells (Shaffery et al. 2012). Mouse LC neuron number is decreased following both intermittent hypoxia interruptions in breathing experienced in sleep apnea and chronic sleep deprivation (Zhu et al. 2007)(Zhang et al. 2014). Following sleep deprivation for 8 hours/day for 3 days, the critical redox homeostasis protein SirT3 is downregulated in LC neurons, and this is associated with increased oxidative stress and a $20 \%$ neuronal loss (Zhang et al. 2014). Reasons for LC susceptibility to stressors such as sleep loss are unclear, but various hypotheses have been proposed. High levels of NADPH oxidase may play a role in contributing to oxidative injury (Zhu et al. 2007)(Zhan et al. 2005), and recent evidence from slice recordings demonstrates that LC neurons experience augmented mitochondrial oxidant stress due to basal calcium oscillations (Sanchez-Padilla et al. 2014).

In addition to its vulnerability to alterations in the sleep-wake cycle, LC appears to be uniquely vulnerable in neurodegenerative disease (Sotiriou et al. 2010)(Von Coelln et al. 2004). The majority of LC noradrenergic neurons are lost in AD, PD, and DLB (Brunnström et al. 2011), to a lesser extent in FTLD (Brunnström et al. 2011), and morphological and histological changes occur in LC of ALS patients as well (Hoogendijk et al. 1995) (Iwanaga et al. 1997). Recently, it was reported that neuron loss in LC of AD and PD patients is even greater than that observed in regions of the forebrain and substantia nigra, respectively (Zarow et al. 2003). Anatomist Heiko Braak has written extensively on his findings regarding the stages of the pathological process in both $\mathrm{AD}$ and PD, and in both cases it is clear that LC pathology occurs long before most other regions incur damage (Braak et al. 2011)(Braak et al. 2004)(but see (Burke et al. 2008) for an alternative view). Suggesting a causal role for this early LC degeneration, toxic lesions of LC in a transgenic mouse model of Alzheimer's disease accelerate $\beta$-amyloid plaque formation, acetylcholinesterase activity reduction, neuronal loss, and onset of memory impairment (Heneka et al. 2006).

The view that early LC degeneration may cause further disease progression is also bolstered by an extensive study compiling cognitive and histological data from 165 elderly individuals without a prior diagnosis (Wilson et al. 2013). Researchers collected data using a battery of cognitive tasks spanning several years, and upon death the subjects' brains were autopsied. In addition to neuronal size and number, researchers quantified neurofibrillary tangles and Lewy Bodies. They found that the presence of these pathological hallmarks in LC, but not 
$\mathrm{SN}$ or other brain regions examined, was strongly correlated with cognitive decline. Based on these data, the authors concluded that neuronal health in LC may determine whether damage to other brain regions will result in neurological symptoms (Wilson et al. 2013). In this scenario, declining function of LC neurons due to sleep fragmentation could accelerate disease progression or even allow new symptoms to emerge as a result of existing degeneration in other brain regions.

Based on the strong correlations between sleep fragmentation, neurodegenerative disease, and LC neuronal loss, it is logical to infer that as sleep patterns change with age, vulnerable noradrenergic neurons of the LC may lose functionality (Zhang et al. 2014) and in turn promote disease onset or progression (Wilson et al. 2013)(Braak et al. 2004). This framework is consistent with EDS being predictive of declines in cognition (Jaussent et al. 2012) and the sleep disorder RBD being the most robust known predictor of PD (Schenck et al. 2013). This also would explain the pathological timeline of disease (Braak et al. 2011)(Braak et al. 2004) and provide a potential contributing explanation for why neurodegeneration occurs most commonly in the elderly, whose sleep is highly fragmented (Schmidt et al. 2012).

\section{Cholinergic neurons of nucleus basalis of Meynert}

A cluster of neurons in the basal forebrain (BF) called the Nucleus Basalis of Meynert (NBM) provides the primary source of cholinergic input to regions throughout the cortex (Gratwicke et al. 2013). NBM is critically involved in cognition (Hasselmo and Sarter 2011), wakefulness (Manfridi et al. 1999), and REM sleep (Steriade 2004), receiving dense projections from other wake-active areas such as LC and TMN (Platt and Riedel 2011).

Atrophy of NBM and other cholinergic nuclei occurs in healthy aging (Grothe et al. 2012)(Wolf et al. 2014) (Sawiak et al. 2014) (but see (Schliebs and Arendt 2011) for an alternative view), along with a drastic reduction in nicotinic acetylcholine receptor expression in cortex (Nordberg et al. 1992). Moreover, existing cholinergic cells may not be as responsive to environmental stimuli (Zhang et al. 2002); this could be due to a number of changes in protein expression patterns, including loss of AMPA receptors (Ikonomovic et al. 2000). Based on the critical role of cholinergic signaling in learning and memory, it is not surprising that basal forebrain volume is correlated with cognitive ability across aging (Wolf et al. 2014).

In rodent models, both sleep deprivation and fragmentation have marked effects on BF. (Kim et al. 2013)(Sims et al. 2013). After 6 hours of sleep deprivation, in vitro studies reveal an inducible nitric oxide synthase (iNOS)dependent increase in adenosine release from BF neurons (Sims et al. 2013), and in vivo studies indicate that increases in iNOS expression occur specifically in wakeactive neurons of NBM (Kalinchuk et al. 2010). This indicates that protein nitrosylation may play a role similarly to the case of orexinergic neurons (Obukuro et al. 2013). Additionally after 6 hours of sleep deprivation adenosine receptor expression is upregulated in BF (Basheer et al. 2007), and after 24 hours of sleep deprivation, levels of $\alpha 1$-adrenergic receptor mRNA in BF are increased as well (Kim et al. 2013).

Similarly to other wake-active regions, NBM neuron numbers are also substantially decreased in neurodegenerative disease, primarily AD (Rogers et al. 1985), PD, (Rogers et al. 1985) and DLB (Grothe et al. 2014)(Iranzo et al. 2014) (although cholinergic systems seem to be uniquely spared in FTLD (Hirano et al. 2010)(Di Lazzaro et al. 2006)). Particularly in AD, selective pathology in cholinergic cells in NBM is an early and defining feature of disease that progresses slowly throughout aging, mild cognitive impairment (MCI), and eventually the first stages of AD (Mesulam et al. 2004). Degeneration of these neurons is likely to play a key role in the progression of symptoms, given that cognition in AD is correlated with BF volume (Grothe et al. 2014), and lower NBM volumes are predictive of cognitive decline in patients with mild cognitive impairment (Grothe et al. 2010). Based on these data as well as the benefit provided by acetylcholinesterase inhibitors for $A D$ patients (Zemek et al. 2014), deep brain stimulation of NBM has recently gained popularity among scientists as a potential therapeutic intervention (Gratwicke et al. 2013). If these strategies prove effective, one implication would be that preservation of NBM integrity through interventions aimed at sleep consolidation could also help to ameliorate disease.

\section{Histaminergic neurons of tuberomammillary nucleus}

The TMN in the hypothalamus is the sole source of the wake-promoting neurotransmitter histamine. The region projects widely throughout the brain and plays a critical role in maintaining circadian rhythms, with direct reciprocal connections to the master circadian clock region suprachiasmatic nucleus (SCN) (Shan et al. 2013). The importance of histaminergic signaling was recently highlighted with the discovery that the effects of orexin on wakefulness are entirely dependent on downstream histamine release (Huang et al. 2001).

Several changes occur in TMN and histamine signaling with aging, although the number of cells is essentially preserved (Shan et al. 2013). Elevated levels of histamine metabolites were identified in the CSF of older subjects (Prell et al. 1988), and decreased expression of histamine receptors in cortex was identified by PET scan (Yanai et al. 1992). This could indicate that an overactive histaminergic system induces receptor downregulation, 
which would be consistent with reports of increased cell size in TMN of older men (Ishunina et al. 2003). However, neither metabolic activity nor expression of histamine synthesizing enzyme histidine decarboxylase (HDC) are altered over the course of aging (Ishunina et al. 2003) (Shan et al. 2013). Based on these somewhat contradictory data, it is likely that age-related changes to the histaminergic system are relatively subtle and complex.

Histamine concentrations in CSF are decreased in patients with EDS (Bassetti et al. 2010), indicating that low histamine may either contribute to sleepiness or be induced by sleep-wake fragmentation. Supporting the latter possibility, sleep deprivation in rats causes a decline in brain histamine levels (Xu et al. 2010). A loss of orexin, however, which results in instability of sleepwake states, is associated with dramatic increases in histaminergic neuron number in both humans and mice (Valko et al. 2013).

The histaminergic system is substantially affected in both $\mathrm{AD}$ and $\mathrm{PD}$. In $\mathrm{AD}$ in particular, dramatic cell loss occurs in TMN (Nakamura et al. 1993)(Shan et al. 2012a) as well as decreased histamine synthesis (FernandezNovoa 2001). However, this is accompanied by increased histamine release at axon terminals (Fernandez-Novoa 2001), which may partially compensate for loss of soma. Interestingly, in PD there is increased arborization of histaminergic terminals as well, particularly in the SN (Anichtchik et al. 2000), but despite the extensive spread of Lewy bodies throughout TMN there is no observed loss of cells or HDC expression (Shan et al. 2012b)(Shan et al. 2013). Presynaptic histamine receptor antagonists, which further increase histamine release, are currently in clinical trials to assess their potential efficacy in mitigating symptoms of both AD (Brioni et al. 2011) and PD (Shan et al. 2013).

\section{Serotonergic neurons of dorsal raphe}

The dorsal raphe (DR) nuclei synthesize the neurotransmitter serotonin (5-HT) and send extensive projections through the telencephalon, brainstem, and cortex. The DR receives inputs from all other wake active neuronal populations (Rodríguez et al. 2012) and plays a critical role in maintaining wakefulness (Monti 2011).

A decrease in 5-HT receptor expression has been reported in healthy aging, but contradictory data have been obtained depending on the organism, brain region, and receptor subtype being studied (Rodríguez et al. 2012) (Marcusson et al. 1984). In addition, aged rats have altered serotonin transporter (SERT) expression, aberrant DR neuronal morphology, and decreased fiber density of 5-HT neurons (Rodríguez et al. 2012)(van Luijtelaar et al. 1988). Despite these changes, however, absolute cell number in DR is well preserved over aging in both rats (van Luijtelaar et al. 1992) and humans (Klöppel et al. 2001).
The effects of acute sleep deprivation and REM sleep deprivation on DR have been well studied, in part because sleep deprivation has high therapeutic efficacy in depressed patients, who are thought to have altered 5HT signaling (Hemmeter et al. 2010). In line with this, animal studies have indeed revealed extensive changes to DR following sleep deprivation, including increases in neuronal size (Ranjan et al. 2010), increased firing during wake (Gardner et al. 1997), and what may be a compensatory downregulation of 5-HT receptors throughout downstream brain regions (Hipólide et al. 2005).

Despite relative preservation of cell number in healthy aging, extensive DR cell loss occurs in $\mathrm{AD}$ (Chen et al. 2000), PD (Halliday et al. 1990), and FTLD (Yang and Schmitt 2001) (although the latter data are controversial see (Rodríguez et al. 2012)), and in all three diseases (Lai et al. 2005)(Politis et al. 2012)(Bowen et al. 2008), as well as in ALS (Turner et al. 2005), reduced 5-HT receptor expression in cortex has also been documented. Reduced CSF concentrations of either 5-HT or its precursor tryptophan are observed in AD (Tohgi et al. 1992), PD (Tohgi et al. 1993), and ALS (Monaco et al. 1979) patients as well. In PD, these decreases in 5-HT concentration are correlated with the severity of motor symptoms (Tohgi et al. 1993), and in AD loss of 5-HT receptor expression in temporal cortex is correlated with cognitive decline (Lai et al. 2005). These data indicate that loss of serotonergic signaling may play a role in disease progression, which is consistent with the observations that DR pathology occurs very early in the development of PD (Braak et al. 2004) and that treatment with selective serotonin reuptake inhibitors (SSRIs) has shown promise in ameliorating AD cognitive symptoms (Mossello et al. 2008). ALS disease progression is likely to be influenced by altered serotonin systems as well, given that motor neurons with dense serotonergic input are preferentially susceptible to degeneration (Sandyk 2006).

\section{Dopaminergic neurons of ventral periaqueductal gray}

The most recently identified wake-active neuronal population is a small group of dopaminergic cells just lateral to the DR called the ventral periaqueductal gray (vPAG). These cells have strongly increased c-fos expression during wakefulness, and their depletion causes an increase in total sleep time in rats (Lu et al. 2006).

Very little has been reported regarding changes to the vPAG during healthy aging, despite extensive attention paid to other dopaminergic systems such as SN and VTA. Based on its recently discovered role in sleep-wake cycle maintenance ( $\mathrm{Lu}$ et al. 2006), future studies may address whether alterations to this region over aging occurs in association with sleep disturbances. There is also a paucity of data regarding effects of sleep disturbances on vPAG, although one study suggests that vPAG may 
be uniquely susceptible to intermittent hypoxia (Zhu et al. 2007). In this study, long term intermittent hypoxia induced high levels of the apoptotic marker cleaved caspase 3 , as well as cell loss, in dopaminergic cells of vPAG but not orexinergic or histaminergic populations (Zhu et al. 2007). However it is unclear whether these changes were due to sleep fragmentation or hypoxia per se.

Regarding disease, loss of vPAG cells (Benarroch et al. 2009) and altered dopamine metabolism (Kumakura et al. 2010) have been reported in PD patients, and vPAG of AD patients (Parvizi et al. 2000) and mouse models of AD (Overk et al. 2009) display extensive NFT and $\beta$-amyloid pathology. Taken together, these studies suggest the possibility of a role for vPAG disturbances in disease, but a larger body of evidence is warranted to clarify whether vPAG pathology represents a unique phase of degeneration or a more generalized feature of widespread neuronal damage.

\section{Conclusion}

Although it is widely documented that sleep fragmentation and EDS are strongly correlated with both aging and neurodegenerative disease, it has proven difficult to define the causal relationships among these features, and the topic remains controversial (Klerman and Dijk 2008) (Gooneratne and Vitiello 2014). One recent human study (Mander et al. 2013) elucidated a role for slow wave sleep loss in the memory retention deficits associated with healthy aging, and found that both factors were associated with atrophy of medial prefrontal cortex. The authors concluded that age-associated cortical atrophy may contribute to sleep changes which in turn impact memory, indicating that interventions aimed at improving sleep among the elderly may have marked benefits on cognitive function even in healthy patients (Miyata et al. 2013).

Several animal studies have now provided plausible mechanistic bases for effects of sleep disturbance on neurodegenerative disease onset or progression as well. For instance, it was recently reported that in mice, interstitial fluid levels of $\beta$-amyloid are increased with both orexin administration and sleep deprivation (Kang et al. 2009), and one of the key functions of sleep may be to allow clearance from the brain of potentially toxic species including $\beta$-amyloid (Xie et al. 2013). Given such studies as well as the breadth of data indicating that loss of sleep and wake consolidation often precedes and predicts neurodegenerative disease (Schenck et al. 2013) (Abbott et al. 2005)(Lim et al. 2013a), scientists should now address whether non-pharmacological (Wennberg et al. 2013) or pharmacological (Wennberg et al. 2013) (Lyseng-Williamson 2012) sleep therapies can decrease the likelihood of disease onset through preservation of wake-active neuronal systems in the elderly population.
Indeed, the sleep-promoting hormone melatonin has been shown not only to increase sleep and improve daytime alertness (Lemoine et al. 2007), but also to improve cognitive scores in AD patients (Wade et al. 2014). Cell culture, animal, and human data indicate that melatonin may stall disease progression in ALS patients as well (Weishaupt et al. 2006).

Each neurodegenerative disease exhibits unique pathology, symptomology, genetic risk factors, and environmental correlates, but sleep disturbances are the one feature common across a wide range of diseases. This highlights a role for sleep in neurodegenerative onset as one of the most parsimonious explanations for emergence of disease, and the failure of wake-active neuronal populations following prolonged sleep disruption provides a mechanistic framework to bolster the likelihood of such a model. As the sleep and neurodegeneration fields begin to foster greater collaboration, we expect to see more studies in both animals and humans to determine whether improving sleep may ameliorate the high disease risks faced by the elderly population.

\section{Competing interests}

The authors declare that they have no competing interests.

\section{Authors' contributions}

AS wrote the review, NN provided guidance and edited the manuscript. Both authors read and approved the final manuscript.

Received: 3 October 2014 Accepted: 23 December 2014

Published online: 17 January 2015

\section{References}

Abbott RD, Ross GW, White LR, Tanner CM, Masaki KH, Nelson JS, Curb JD, Petrovitch H (2005) Excessive daytime sleepiness and subsequent development of Parkinson disease. Neurology 65:1442-1446, doi:10.1212/01. wnl.0000183056.89590.0d

Adamantidis AR, Zhang F, Aravanis AM, Deisseroth K, de Lecea L (2007) Neural substrates of awakening probed with optogenetic control of hypocretin neurons. Nature 450:420-424, doi:10.1038/nature06310

Anderson KN, Hatfield C, Kipps C, Hastings M, Hodges JR (2009) Disrupted sleep and circadian patterns in frontotemporal dementia. Eur J Neurol 16:317-323, doi:10.1111/j.1468-1331.2008.02414.x

Anichtchik OV, Rinne JO, Kalimo H, Panula P (2000) An altered histaminergic innervation of the substantia nigra in Parkinson's disease. Exp Neurol 163:20-30, doi:10.1006/exnr.2000.7362

Arnulf I, Leu-Semenescu S (2009) Sleepiness in Parkinson's disease. Parkinsonism Relat Disord 15(Suppl 3):S101-S104, doi:10.1016/S1353-8020(09)70792-8

Basheer R, Bauer A, Elmenhorst D, Ramesh V, McCarley RW (2007) Sleep deprivation upregulates $A 1$ adenosine receptors in the rat basal forebrain. Neuroreport 18:1895-1899, doi:10.1097/WNR.0b013e3282f262f6

Bassetti CL, Baumann CR, Dauvilliers Y, Croyal M, Robert P, Schwartz JC (2010) Cerebrospinal fluid histamine levels are decreased in patients with narcolepsy and excessive daytime sleepiness of other origin. J Sleep Res 19:620-623, doi:10.1111/j.1365-2869.2010.00819.x

Benarroch EE, Schmeichel AM, Dugger BN, Sandroni P, Parisi JE, Low PA (2009) Dopamine cell loss in the periaqueductal gray in multiple system atrophy and Lewy body dementia. Neurology 73:106-112, doi:10.1212/ WNL.0b013e3181ad53e7

Bixler EO, Vgontzas AN, Lin H-M, Calhoun SL, Vela-Bueno A, Kales A (2005) Excessive daytime sleepiness in a general population sample: the role of sleep apnea, age obesity, diabetes, and depression. J Clin Endocrinol Metab 90:4510-4515, doi:10.1210/jc.2005-0035

Bliwise DL (1993) Sleep in normal aging and dementia. Sleep 16:40-81 
Bloom GS (2014) Amyloid- $\beta$ and tau: the trigger and bullet in Alzheimer disease pathogenesis. JAMA Neurol 71:505-508, doi:10.1001/jamaneurol.2013.5847

Boeve BF, Silber MH, Saper CB, Ferman TJ, Dickson DW, Parisi JE, Benarroch EE, Ahlskog JE, Smith GE, Caselli RC, Tippman-Peikert M, Olson E, Lin SC, Young T, Wszolek Z, Schenck CH, Mahowald MW, Castillo PR, Del Tredici K, Braak H (2007) Pathophysiology of REM sleep behaviour disorder and relevance to neurodegenerative disease. Brain 130:2770-2788, doi:10.1093/brain/awm056

Bolitho SJ, Naismith SL, Salahuddin P, Terpening Z, Grunstein RR, Lewis SJ (2013) Objective measurement of daytime napping, cognitive dysfunction and subjective sleepiness in Parkinson's disease. PLoS One 8:e81233, doi:10.1371/ journal.pone.0081233

Bonakis A, Economou N-T, Paparrigopoulos T, Bonanni E, Maestri M, Carnicelli L, Di Coscio E, Ktonas P, Vagiakis E, Theodoropoulos P, Papageorgiou SG (2014) Sleep in frontotemporal dementia is equally or possibly more disrupted, and at an earlier stage, when compared to sleep in Alzheimer's disease. J Alzheimers Dis 38:85-91, doi:10.3233/JAD-122014

Bonanni E, Maestri M, Tognoni G, Fabbrini M, Nucciarone B, Manca ML, Gori S, ludice A, Murri L (2005) Daytime sleepiness in mild and moderate Alzheimer's disease and its relationship with cognitive impairment. J Sleep Res 14:311-317, doi:10.1111/j.1365-2869.2005.00462.x

Bouras C, Hof PR, Giannakopoulos P, Michel JP, Morrison JH (1994) Regional distribution of neurofibrillary tangles and senile plaques in the cerebral cortex of elderly patients: a quantitative evaluation of a one-year autopsy population from a geriatric hospital. Cereb Cortex 4:138-50

Bowen DM, Procter AW, Mann DMA, Snowden JS, Esiri MM, Neary D, Francis PT (2008) Imbalance of a serotonergic system in frontotemporal dementia: implication for pharmacotherapy. Psychopharmacology (Berl) 196:603-610, doi:10.1007/s00213-007-0992-8

Braak H, Ghebremedhin E, Rüb U, Bratzke H, Del Tredici K (2004) Stages in the development of Parkinson's disease-related pathology. Cell Tissue Res 318:121-134, doi:10.1007/s00441-004-0956-9

Braak H, Thal DR, Ghebremedhin E, Del Tredici K (2011) Stages of the pathologic process in Alzheimer disease: age categories from 1 to 100 years. J Neuropathol Exp Neurol 70:960-969, doi:10.1097/NEN.0b013e318232a379

Brioni JD, Esbenshade TA, Garrison TR, Bitner SR, Cowart MD (2011) Discovery of histamine $\mathrm{H} 3$ antagonists for the treatment of cognitive disorders and Alzheimer's disease. J Pharmacol Exp Ther 336:38-46, doi:10.1124/ jpet.110.166876

Brown MK, Naidoo N (2012) The endoplasmic reticulum stress response in aging and age-related diseases. Front Physiol 3:263, doi:10.3389/fphys.2012.00263

Brownell SE, Conti B (2010) Age- and gender-specific changes of hypocretin immunopositive neurons in C57BI/6 mice. Neurosci Lett 472:29-32, doi:10.1016/j.neulet.2010.01.048

Brunnström H, Friberg N, Lindberg E, Englund E (2011) Differential degeneration of the locus coeruleus in dementia subtypes. Clin Neuropathol 30:104-10

Burke RE, Dauer WT, Vonsattel JPG (2008) A critical evaluation of the Braak staging scheme for Parkinson's disease. Ann Neurol 64:485-491, doi:10.1002/ana.21541

Carter ME, Yizhar O, Chikahisa S, Nguyen H, Adamantidis A, Nishino S, Deisseroth $K$, de Lecea $L$ (2010) Tuning arousal with optogenetic modulation of locus coeruleus neurons. Nat Neurosci 13:1526-1533, doi:10.1038/nn.2682

Chemelli RM, Willie JT, Sinton CM, Elmquist JK, Scammell T, Lee C, Richardson JA, Williams SC, Xiong Y, Kisanuki Y, Fitch TE, Nakazato M, Hammer RE, Saper CB, Yanagisawa M (1999) Narcolepsy in orexin knockout mice molecular genetics of sleep regulation. Cell 98:437-451, doi:10.1016/S0092-8674(00)81973-X

Chen CPL-H, Eastwood SL, Hope T, McDonald B, Francis PT, Esiri MM (2000) Immunocytochemical study of the dorsal and median raphe nuclei in patients with Alzheimer's disease prospectively assessed for behavioural changes. Neuropathol Appl Neurobiol 26:347-355, doi:10.1046/j.13652990.2000.00254.x

Çoban A, Bilgiç B, Lohmann E, Küçükali Cl, Benbir G, Karadeniz D, Hanagasi HA, Tüzün E, Gürvit H (2013) Reduced orexin-A levels in frontotemporal dementia: possible association with sleep disturbance. Am J Alzheimers Dis Other Demen 28:606-611, doi:10.1177/1533317513494453

Conte F, Arzilli C, Errico BM, Giganti F, lovino D, Ficca G (2014) Sleep measures expressing "functional uncertainty" in elderlies' sleep. Gerontology 60:448-457, doi:10.1159/000358083

De Cock VC, Vidailhet M, Arnulf I (2008) Sleep disturbances in patients with parkinsonism. Nat Clin Pract Neurol 4:254-266, doi:10.1038/ncpneuro0775

De Lecea L, Huerta R (2014) Hypocretin (orexin) regulation of sleep-to-wake transitions. Front Pharmacol 5:16, doi:10.3389/fphar.2014.00016
De Lecea L, Kilduff TS, Peyron C, Gao X, Foye PE, Danielson PE, Fukuhara C, Battenberg EL, Gautvik VT, Bartlett FS 2nd, Frankel WN, van den Pol AN, Bloom FE, Gautvik KM, Sutcliffe JG (1998) The hypocretins: hypothalamusspecific peptides with neuroexcitatory activity. Proc Natl Acad Sci 95:322-327, doi:10.1073/pnas.95.1.322

Di Lazzaro V, Pilato F, Dileone M, Saturno E, Oliviero A, Marra C, Daniele A, Ranieri F, Gainotti G, Tonali PA (2006) In vivo cholinergic circuit evaluation in frontotemporal and Alzheimer dementias. Neurology 66:1111-1113, doi:10.1212/01.wnl.0000204183.26231.23

Downs JL, Dunn MR, Borok E, Shanabrough M, Horvath TL, Kohama SG, Urbanski HF (2007) Orexin neuronal changes in the locus coeruleus of the aging rhesus macaque. Neurobiol Aging 28:1286-1295, doi:10.1016/j. neurobiolaging.2006.05.025

Fernandez-Novoa L (2001) Histamine function in brain disorders. Behav Brain Res 124:213-233, doi:10.1016/S0166-4328(01)00215-7

Foley DJ, Vitiello MV, Bliwise DL, Ancoli-Israel S, Monjan AA, Walsh JK (2007) Frequent napping is associated with excessive daytime sleepiness, depression, pain, and nocturia in older adults: findings from the national sleep foundation "2003 Sleep in America" Poll. Am J Geriatr psychiatry 15:344-350, doi:10.1097/01. JGP.0000249385.50101.67

Fronczek R, Overeem S, Lee SYY, Hegeman IM, van Pelt J, van Duinen SG, Lammers GJ, Swaab DF (2007) Hypocretin (orexin) loss in Parkinson's disease. Brain 130:1577-1585, doi:10.1093/brain/awm090

Fronczek R, van Geest S, Frölich M, Overeem S, Roelandse FW, Lammers GJ, Swaab DF (2012) Hypocretin (orexin) loss in Alzheimer's disease. Neurobiol Aging 33:1642-1650, doi:10.1016/j.neurobiolaging.2011.03.014

Gardner JP, Fornal CA, Jacobs BL (1997) Effects of sleep deprivation on serotonergic neuronal activity in the dorsal raphe nucleus of the freely moving cat. Neuropsychopharmacology 17:72-81, doi:10.1016/S0893133X(97)00025-0

Gong Y, Xiong K-P, Mao C-J, Shen Y, Hu WD, Huang JY, Han F, Chen R, Liu CF (2014) Clinical manifestations of Parkinson disease and the onset of rapid eye movement sleep behavior disorder. Sleep Med 15:647-653, doi:10.1016/j. sleep.2013.12.021

González MMC, Aston-Jones G (2006) Circadian regulation of arousal: role of the noradrenergic locus coeruleus system and light exposure. Sleep 29:1327-1336

Gooneratne NS, Vitiello MV (2014) Sleep in older adults: normative changes, sleep disorders, and treatment options. Clin Geriatr Med 30:591-627, doi:10.1016/j. cger.2014.04.007

Gratwicke J, Kahan J, Zrinzo L, Hariz M, Limousin P, Foltynie T, Jahanshahi M (2013) The nucleus basalis of Meynert: a new target for deep brain stimulation in dementia? Neurosci Biobehav Rev 37:2676-2688, doi:10.1016/j. neubiorev.2013.09.003

Grivel J, Cvetkovic V, Bayer L, Machard D, Tobler I, Mühlethaler M, Serafin M (2005) The wake-promoting hypocretin/orexin neurons change their response to noradrenaline after sleep deprivation. J Neurosci 25:4127-4130, doi:10.1523/JNEUROSCI.0666-05.2005

Grothe M, Zaborszky L, Atienza M, Gil-Neciga E, Rodriguez-Romero R, Teipel SJ, Amunts K, Suarez-Gonzalez A, Cantero JL (2010) Reduction of basal forebrain cholinergic system parallels cognitive impairment in patients at high risk of developing Alzheimer's disease. Cereb Cortex 20:1685-1695, doi:10.1093/ cercor/bhp232

Grothe M, Heinsen H, Teipel SJ (2012) Atrophy of the cholinergic Basal forebrain over the adult age range and in early stages of Alzheimer's disease. Biol Psychiatry 71:805-813, doi:10.1016/j.biopsych.2011.06.019

Grothe MJ, Schuster C, Bauer F, Heinsen H, Prudlo J, Teipel SJ. (2014) Atrophy of the cholinergic basal forebrain in dementia with Lewy bodies and Alzheimer's disease dementia. J Neurol 1-10. doi:10.1007/s00415-014-7439-z

Grudzien A, Shaw P, Weintraub S, Bigio E, Mash DC, Mesulam MM (2007) Locus coeruleus neurofibrillary degeneration in aging, mild cognitive impairment and early Alzheimer's disease. Neurobiol Aging 28:327-335, doi:10.1016/j. neurobiolaging.2006.02.007

Guarnieri B, Adorni F, Musicco M, Appollonio I, Bonanni E, Caffarra P Caltagirone C, Cerroni G, Concari L, Cosentino Fl, Ferrara S, Fermi S, Ferri R, Gelosa G, Lombardi G, Mazzei D, Mearelli S, Morrone E, Murri L, Nobili FM, Passero S, Perri R, Rocchi R, Sucapane P, Tognoni G, Zabberoni S, Sorbi S (2012) Prevalence of sleep disturbances in mild cognitive impairment and dementing disorders: a multicenter Italian clinical cross-sectional study on 431 patients. Dement Geriatr Cogn Disord 33:50-58, doi:10.1159/000335363 
Halliday GM, Blumbergs PC, Cotton RG, Blessing WW, Geffen LB (1990) Loss of brainstem serotonin- and substance P-containing neurons in Parkinson's disease. Brain Res 510:104-107

Halloran M, Parakh S, Atkin JD (2013) The role of s-nitrosylation and sglutathionylation of protein disulphide isomerase in protein misfolding and neurodegeneration. Int J Cell Biol 2013:797914, doi:10.1155/2013/797914

Hasselmo ME, Sarter M (2011) Modes and models of forebrain cholinergic neuromodulation of cognition. Neuropsychopharmacology 36:52-73, doi:10.1038/npp.2010.104

Hemmeter U-M, Hemmeter-Spernal J, Krieg J-C (2010) Sleep deprivation in depression. Expert Rev Neurother 10:1101-1115, doi:10.1586/ern.10.83

Heneka MT, Ramanathan M, Jacobs AH, Dumitrescu-Ozimek L, Bilkei-Gorzo A, Debeir T, Sastre M, Galldiks N, Zimmer A, Hoehn M, Heiss WD, Klockgether T, Staufenbiel M (2006) Locus ceruleus degeneration promotes Alzheimer pathogenesis in amyloid precursor protein 23 transgenic mice. J Neurosci 26:1343-1354, doi:10.1523/JNEUROSCI.4236-05.2006

Hipólide DC, Moreira KM, Barlow KBL, Wilson AA, Nobrega JN, Tufik S (2005) Distinct effects of sleep deprivation on binding to norepinephrine and serotonin transporters in rat brain. Prog Neuropsychopharmacol Biol Psychiatry 29:297-303, doi:10.1016/j.pnpbp.2004.11.015

Hirano S, Shinotoh H, Shimada H, Aotsuka A, Tanaka N, Ota T, Sato K, Ito H, Kuwabara S, Fukushi K, Irie T, Suhara T (2010) Cholinergic imaging in corticobasal syndrome, progressive supranuclear palsy and frontotemporal dementia. Brain 133:2058-2068, doi:10.1093/brain/awq120

Hoogendijk WJ, Pool CW, Troost D, van Zwieten E, Swaab DF (1995) Image analyser-assisted morphometry of the locus coeruleus in Alzheimer's disease, Parkinson's disease and amyotrophic lateral sclerosis. Brain 118(Pt 1):131-143

Huang ZL, Qu WM, Li WD, Mochizuki T, Eguchi N, Watanabe T, Urade Y, Hayaishi O (2001) Arousal effect of orexin A depends on activation of the histaminergic system. Proc Natl Acad Sci U S A 98:9965-9970, doi:10.1073/pnas.181330998

Ikonomovic MD, Nocera R, Mizukami K, Armstrong DM (2000) Age-related loss of the AMPA receptor subunits GluR2/3 in the human nucleus basalis of Meynert. Exp Neurol 166:363-375, doi:10.1006/exnr.2000.7544

Iraizoz I, Guijarro JL, Gonzalo LM, de Lacalle S (1999) Neuropathological changes in the nucleus basalis correlate with clinical measures of dementia. Acta Neuropathol 98:186-196

Iranzo A, Gelpi E, Tolosa E, Molinuevo JL, Serradell M, Gaig C, Santamaria J (2014) Neuropathology of prodromal Lewy body disease. Mov Disord 29:410-415, doi:10.1002/mds.25825

Ishunina TA, van Heerikhuize JJ, Ravid R, Swaab DF (2003) Estrogen receptors and metabolic activity in the human tuberomamillary nucleus: changes in relation to sex, aging and Alzheimer's disease. Brain Res 988:84-96, doi:10.1016/S0006-8993(03)03347-X

Iwanaga K, Wakabayashi K, Honma Y, Takahashi H (1997) Amyotrophic lateral sclerosis: occurrence of Bunina bodies in the locus ceruleus pigmented neurons. Clin Neuropathol 16:23-6

Jaussent I, Bouyer J, Ancelin M-L, Berr C, Foubert-Samier A, Ritchie K, Ohayon MM, Besset A, Dauvilliers Y (2012) Excessive sleepiness is predictive of cognitive decline in the elderly. Sleep 35:1201-1207, doi:10.5665/sleep.2070

Kalinchuk AV, McCarley RW, Porkka-Heiskanen T, Basheer R (2010) Sleep deprivation triggers inducible nitric oxide-dependent nitric oxide production in wake-active basal forebrain neurons. J Neurosci 30:13254-13264, doi:10.1523/JNEUROSCI.0014-10.2010

Kang J-E, Lim MM, Bateman RJ, Lee JJ, Smyth LP, Cirrito JR, Fujiki N, Nishino S, Holtzman DM (2009) Amyloid-beta dynamics are regulated by orexin and the sleep-wake cycle. Science 326:1005-1007, doi:10.1126/science.1180962

Karageorgiou E, Miller BL (2014) Frontotemporal lobar degeneration: a clinical approach. Semin Neurol 34:189-201, doi:10.1055/s-0034-1381735

Kessler BA, Stanley EM, Frederick-Duus D, Fadel J (2011) Age-related loss of orexin/hypocretin neurons. Neuroscience 178:82-88, doi:10.1016/j. neuroscience.2011.01.031

Kim Y, Chen L, McCarley RW, Strecker RE (2013) Sleep allostasis in chronic sleep restriction: the role of the norepinephrine system. Brain Res 1531:9-16, doi:10.1016/j.brainres.2013.07.048

Klerman EB, Dijk D-J (2008) Age-related reduction in the maximal capacity for sleep-implications for insomnia. Curr Biol 18:1118-1123, doi:10.1016/j. cub.2008.06.047

Klöppel S, Kovacs GG, Voigtländer T, Wanschitz J, Flicker H, Hainfellner JA, Guentchev M, Budka H (2001) Serotonergic nuclei of the raphe are not affected in human ageing. Neuroreport 12:669-671
Kumakura Y, Danielsen EH, Gjedde A, Vernaleken I, Buchholz HG, Heinz A, Gründer G, Bartenstein P, Cumming P (2010) Elevated [(18)F]FDOPA utilization in the periaqueductal gray and medial nucleus accumbens of patients with early Parkinson's disease. Neuroimage 49:2933-2939, doi:10.1016/j.neuroimage.2009.11.035

Lai MK, Tsang SW, Alder JT, Keene J, Hope T, Esiri MM, Francis PT, Chen CP (2005) Loss of serotonin 5-HT2A receptors in the postmortem temporal cortex correlates with rate of cognitive decline in Alzheimer's disease. Psychopharmacology (Berl) 179:673-677, doi:10.1007/s00213-004-2077-2

Langston JW, Foltynie T, Kahan J (2013) Parkinson's disease: an update on pathogenesis and treatment. J Neurol. doi:10.1007/s00415-013-6915-1

Lemoine P, Nir T, Laudon M, Zisapel N (2007) Prolonged-release melatonin improves sleep quality and morning alertness in insomnia patients aged 55 years and older and has no withdrawal effects. J Sleep Res 16:372-380, doi:10.1111/j.1365-2869.2007.00613.x

Lessig S, Ubhi K, Galasko D, Adame A, Pham E, Remidios K, Chang M, Hansen LA, Masliah E (2010) Reduced hypocretin (orexin) levels in dementia with Lewy bodies. Neuroreport 21:756-760, doi:10.1097/ WNR.0b013e32833bfb7c

Li Y, Panossian LA, Zhang J, Zhu Y, Zhan G, Chou YT, Fenik P, Bhatnagar S, Piel DA, Beck SG, Veasey S (2013) Effects of Chronic Sleep Fragmentation on Wake-Active Neurons and the Hypercapneic Arousal Response. Sleep 37:51-64

Lim ASP, Kowgier M, Yu L, Buchman AS, Bennett DA (2013a) Sleep fragmentation and the risk of incident Alzheimer's disease and cognitive decline in older persons. Sleep 36:1027-1032, doi:10.5665/sleep.2802

Lim ASP, Yu L, Kowgier M, Schneider JA, Buchman AS, Bennett DA (2013b) Modification of the relationship of the apolipoprotein $E \varepsilon 4$ allele to the risk of Alzheimer disease and neurofibrillary tangle density by sleep. JAMA Neurol 70:1544-1551, doi:10.1001/jamaneurol.2013.4215

Lima MMS (2013) Sleep disturbances in Parkinson's disease: The contribution of dopamine in REM sleep regulation. Sleep Med Rev. doi:10.1016/j. smrv.2012.10.006

Lin L, Faraco J, Li R, Kadotani H, Rogers W, Lin X, Qiu X, de Jong PJ, Nishino S, Mignot $E$ (1999) The sleep disorder canine narcolepsy is caused by a mutation in the Hypocretin (Orexin) receptor 2 gene. Cell 98:365-376, doi:10.1016/S0092-8674(00)81965-0

Lo Coco D, La Bella V (2012) Fatigue, sleep, and nocturnal complaints in patients with amyotrophic lateral sclerosis. Eur J Neurol 19:760-763, doi:10.1111/ j.1468-1331.2011.03637.x

Lo Coco D, Mattaliano P, Spataro R, Mattaliano A, La Bella V (2011) Sleep-wake disturbances in patients with amyotrophic lateral sclerosis. J Neurol Neurosurg Psychiatry 82:839-842, doi:10.1136/jnnp.2010.228007

Lu J, Jhou TC, Saper CB (2006) Identification of wake-active dopaminergic neurons in the ventral periaqueductal gray matter. J Neurosci 26:193-202, doi:10.1523/JNEUROSCI.2244-05.2006

Lyseng-Williamson KA (2012) Melatonin prolonged release: in the treatment of insomnia in patients aged $\geq 55$ years. Drugs Aging 29:911-923, doi:10.1007/ s40266-012-0018-Z

Mander BA, Rao V, Lu B, Saletin JM, Lindquist JR, Ancoli-Israel S, Jagust W, Walker MP (2013) Prefrontal atrophy, disrupted NREM slow waves and impaired hippocampal-dependent memory in aging. Nat Neurosci 16:357-364, doi:10.1038/nn.3324

Manfridi A, Brambilla D, Mancia M (1999) Stimulation of NMDA and AMPA receptors in the rat nucleus basalis of Meynert affects sleep. Am J Physiol 277:R1488-R1492

Marcusson JO, Morgan DG, Winblad B, Finch CE (1984) Serotonin-2 binding sites in human frontal cortex and hippocampus. Selective loss of S-2A sites with age. Brain Res 311:51-56, doi:10.1016/0006-8993(84)91397-0

Matsuki T, Takasu M, Hirose Y, Murakoshi N, Sinton CM, Motoike T, Yanagisawa M (2014) GABAA receptor-mediated input change on orexin neurons following sleep deprivation in mice. Neuroscience 284C:217-224, doi:10.1016/j. neuroscience.2014.09.063

Matsuoka T, Fujii N, Kondo A, Iwaki A, Hokonohara T, Honda H, Sasaki K, Suzuki SO, Iwaki T (2011) An autopsied case of sporadic adult-onset amyotrophic lateral sclerosis with FUS-positive basophilic inclusions. Neuropathology 31:71-76, doi:10.1111/j.1440-1789.2010.01129.x

Merlino G, Piani A, Gigli GL, Cancelli I, Rinaldi A, Baroselli A, Serafini A, Zanchettin B, Valente M (2010) Daytime sleepiness is associated with dementia and cognitive decline in older Italian adults: a population-based study. Sleep Med 11:372-377, doi:10.1016/j.sleep.2009.07.018 
Mesulam M, Shaw P, Mash D, Weintraub S (2004) Cholinergic nucleus basalis tauopathy emerges early in the aging-MCl-AD continuum. Ann Neurol 55:815-828, doi:10.1002/ana.20100

Miyata S, Noda A, Iwamoto K, Kawano N, Okuda M, Ozaki N (2013) Poor sleep quality impairs cognitive performance in older adults. J Sleep Res 22:535-541, doi:10.1111/jsr.12054

Monaco F, Fumero S, Mondino A, Mutani R (1979) Plasma and cerebrospinal fluid tryptophan in multiple sclerosis and degenerative diseases. J Neurol Neurosurg Psychiatry 42:640-641

Monti JM (2011) Serotonin control of sleep-wake behavior. Sleep Med Rev 15:269-281, doi:10.1016/j.smrv.2010.11.003

Mossello E, Boncinelli M, Caleri V, Cavallini MC, Palermo E, Di Bari M, Tilli S, Sarcone E, Simoni D, Biagini CA, Masotti G, Marchionni N (2008) Is antidepressant treatment associated with reduced cognitive decline in Alzheimer's disease? Dement Geriatr Cogn Disord 25:372-379, doi:10.1159/000121334

Mouton PR, Pakkenberg B, Gundersen HJG, Price DL (1994) Absolute number and size of pigmented locus coeruleus neurons in young and aged individuals. J Chem Neuroanat 7:185-190, doi:10.1016/0891-0618(94)90028-0

Naidoo N, Zhu J, Zhu Y, Fenik P, Lian J, Galante R, Veasey S (2011) Endoplasmic reticulum stress in wake-active neurons progresses with aging. Aging Cell 10:640-649, doi:10.1111/j.1474-9726.2011.00699.x

Nakamura S, Takemura M, Ohnishi K, Suenaga T, Nishimura M, Akiguchi I, Kimura J, Kimura T (1993) Loss of large neurons and occurrence of neurofibrillary tangles in the tuberomammillary nucleus of patients with Alzheimer's disease. Neurosci Lett 151:196-199

Nordberg A, Alafuzoff I, Winblad B (1992) Nicotinic and muscarinic subtypes in the human brain: changes with aging and dementia. J Neurosci Res 31:103-111, doi:10.1002/jnr.490310115

Obukuro K, Nobunaga M, Takigawa M, Morioka H, Hisatsune A, Isohama Y, Shimokawa H, Tsutsui M, Katsuki H (2013) Nitric oxide mediates selective degeneration of hypothalamic orexin neurons through dysfunction of protein disulfide isomerase. J Neurosci 33:12557-12568, doi:10.1523/ JNEUROSCI.0595-13.2013

Ohayon MM, Carskadon MA, Guilleminault C, Vitiello MV (2004) Meta-analysis of quantitative sleep parameters from childhood to old age in healthy individuals: developing normative sleep values across the human lifespan. Sleep 27:1255-1273

Ohm TG, Busch C, Bohl J (1997) Unbiased estimation of neuronal numbers in the human nucleus coeruleus during aging. Neurobiol Aging 18:393-399, doi:10.1016/S0197-4580(97)00034-1

Overk CR, Kelley CM, Mufson EJ (2009) Brainstem Alzheimer's-like pathology in the triple transgenic mouse model of Alzheimer's disease. Neurobiol Dis 35:415-425, doi:10.1016/j.nbd.2009.06.004

Parkinson J (2002) An essay on the shaking palsy. J Neuropsychiatr 14:223-236, doi:10.1176/appi.neuropsych.14.2.223

Parvizi J, Van Hoesen GW, Damasio A (2000) Selective pathological changes of the periaqueductal gray matter in Alzheimer's disease. Ann Neurol 48:344-353

Pat-Horenczyk R, Klauber MR, Shochat T, Ancoli-Israel S (1998) Hourly profiles of sleep and wakefulness in severely versus mild-moderately demented nursing home patients. Aging (Milano) 10:308-315

Peter-Derex L, Yammine P, Bastuji H, Croisile B (2014) Sleep and Alzheimer's disease. Sleep Med Rev 1-10. doi:10.1016/j.smrv.2014.03.007

Peyron C, Tighe DK, van den Pol AN, de Lecea L, Heller HC, Sutcliffe JG, Kilduff TS (1998) Neurons containing hypocretin (Orexin) project to multiple neuronal systems. J Neurosci 18:9996-10015

Platt B, Riedel G (2011) The cholinergic system, EEG and sleep. Behav Brain Res 221:499-504, doi:10.1016/j.bbr.2011.01.017

Politis M, Wu K, Loane C, Quinn NP, Brooks DJ, Oertel WH, Björklund A, Lindvall O, Piccini P (2012) Serotonin neuron loss and nonmotor symptoms continue in Parkinson's patients treated with dopamine grafts. Sci Transl Med 4:128ra41, doi:10.1126/scitranslmed.3003391

Prell GD, Khandelwal JK, Burns RS, LeWitt PA, Green JP (1988) Elevated levels of histamine metabolites in cerebrospinal fluid of aging, healthy humans. Compr Gerontol A 2:114-119

Ranjan A, Biswas S, Mallick BN (2010) Cytomorphometric changes in the dorsal raphe neurons after rapid eye movement sleep deprivation are mediated by noradrenalin in rats. Behav Brain Funct 6:62, doi:10.1186/1744-9081-6-62

Reid KJ, Martinovich Z, Finkel S, Statsinger J, Golden R, Harter K, Zee PC (2006) Sleep: a marker of physical and mental health in the elderly. Am J Geriatr Psychiatry 14:860-866, doi:10.1097/01.JGP.0000206164.56404.ba
Rodríguez JJ, Noristani HN, Verkhratsky A (2012) The serotonergic system in ageing and Alzheimer's disease. Prog Neurobiol 99:15-41, doi:10.1016/j. pneurobio.2012.06.010

Roenneberg T, Kuehnle T, Pramstaller PP, Ricken J, Havel M, Guth A, Merrow M (2004) A marker for the end of adolescence. Curr Biol 14:R1038-R1039, doi:10.1016/j.cub.2004.11.039

Rogers JD, Brogan D, Mirra SS (1985) The nucleus basalis of Meynert in neurological disease: a quantitative morphological study. Ann Neurol 17:163-170, doi:10.1002/ana.410170210

Roussel BD, Kruppa AJ, Miranda E, Crowther DC, Lomas DA, Marciniak SJ (2013) Endoplasmic reticulum dysfunction in neurological disease. Lancet Neurol 12:105-118, doi:10.1016/S1474-4422(12)70238-7

Rowland LP (2010) Ameliorating amyotrophic lateral sclerosis. N Engl J Med 362:953-954, doi:10.1056/NEJMcibr0912229

Samuels ER, Szabadi E (2008) Functional neuroanatomy of the noradrenergic locus coeruleus: its roles in the regulation of arousal and autonomic function part I: principles of functional organisation. Curr Neuropharmacol 6:235-253, doi:10.2174/157015908785777229

Sanchez-Padilla J, Guzman JN, Ilijic E, Kondapalli J, Galtieri DJ, Yang B, Schieber S, Oertel W, Wokosin D, Schumacker PT, Surmeier DJ (2014) Mitochondrial oxidant stress in locus coeruleus is regulated by activity and nitric oxide synthase. Nat Neurosci 17:832-840, doi:10.1038/nn.3717

Sandyk R (2006) Serotonergic mechanisms in amyotrophic lateral sclerosis. Int J Neurosci 116:775-826, doi:10.1080/00207450600754087

Sawiak SJ, Picq J-L, Dhenain M (2014) Voxel-based morphometry analyses of in vivo MRI in the aging mouse lemur primate. Front Aging Neurosci 6:82, doi:10.3389/fnagi.2014.00082

Schenck CH, Boeve BF, Mahowald MW (2013) Delayed emergence of a parkinsonian disorder or dementia in $81 \%$ of older men initially diagnosed with idiopathic rapid eye movement sleep behavior disorder: a 16-year update on a previously reported series. Sleep Med 14:744-748, doi:10.1016/j.sleep.2012.10.009

Schliebs R, Arendt T (2011) The cholinergic system in aging and neuronal degeneration. Behav Brain Res 221:555-563, doi:10.1016/j.bbr.2010.11.058

Schmidt C, Peigneux P, Cajochen C (2012) Age-related changes in sleep and circadian rhythms: impact on cognitive performance and underlying neuroanatomical networks. Front Neurol 3:118, doi:10.3389/ fneur.2012.00118

Seidel K, Mahlke J, Siswanto S, Krüger R, Heinsen H, Auburger G, Bouzrou M, Grinberg LT, Wicht H, Korf HW, den Dunnen W, Rüb U. (2014) The brainstem pathologies of Parkinson's disease and dementia with Lewy bodies. Brain Pathol. doi:10.1111/bpa.12168

Shaffery JP, Allard JS, Manaye KF, Roffwarg HP (2012) Selective rapid eye movement sleep deprivation affects cell size and number in kitten locus coeruleus. Front Neurol 3:69, doi:10.3389/fneur.2012.00069

Shan L, Bossers K, Unmehopa U, Bao AM, Swaab DF (2012a) Alterations in the histaminergic system in Alzheimer's disease: a postmortem study. Neurobiol Aging 33:2585-2598, doi:10.1016/j.neurobiolaging.2011.12.026

Shan L, Liu C-Q, Balesar R, Hofman MA, Bao AM, Swaab DF (2012b) Neuronal histamine production remains unaltered in Parkinson's disease despite the accumulation of Lewy bodies and Lewy neurites in the tuberomamillary nucleus. Neurobiol Aging 33:1343-1344, doi:10.1016/j.neurobiolaging.2011.01.004

Shan L, Swaab DF, Bao A-M (2013) Neuronal histaminergic system in aging and age-related neurodegenerative disorders. Exp Gerontol 48:603-607, doi:10.1016/j.exger.2012.08.002

Shibata E, Sasaki M, Tohyama K, Kanbara Y, Otsuka K, Ehara S, Sakai A (2006) Age-related changes in locus ceruleus on neuromelanin magnetic resonance imaging at 3 Tesla. Magn Reson Med Sci 5:197-200

Shirokawa T, Ishida Y, Isobe K (2003) Age-related changes in the release and uptake activity of presynaptic axon terminals of rat locus coeruleus neurons. Neurosci Lett 344:212-214, doi:10.1016/S0304-3940(03)00463-4

Shores MM, White SS, Veith RC, Szot P (1999) Tyrosine hydroxylase mRNA is increased in old age and norepinephrine uptake transporter mRNA is decreased in middle age in locus coeruleus of Brown-Norway rats. Brain Res 826:143-147

Sims RE, Wu HHT, Dale N (2013) Sleep-wake sensitive mechanisms of adenosine release in the basal forebrain of rodents: an in vitro study. PLoS One 8: e53814, doi:10.1371/journal.pone.0053814

Sotiriou E, Vassilatis DK, Vila M, Stefanis L (2010) Selective noradrenergic vulnerability in a-synuclein transgenic mice. Neurobiol Aging 31:2103-2114, doi:10.1016/j.neurobiolaging.2008.11.010 
Stanley EM, Fadel J (2012) Aging-related deficits in orexin/hypocretin modulation of the septohippocampal cholinergic system. Synapse 66:445-452, doi:10.1002/syn.21533

Steriade M (2004) Acetylcholine systems and rhythmic activities during the wakingsleep cycle. Prog Brain Res 145:179-196, doi:10.1016/S0079-6123(03)45013-9

Takahashi K, Kayama Y, Lin JS, Sakai K (2010) Locus coeruleus neuronal activity during the sleep-waking cycle in mice. Neuroscience 169:1115-1126, doi:10.1016/j.neuroscience.2010.06.009

Thannickal TC, Moore RY, Nienhuis R, Ramanathan L, Gulyani S, Aldrich M, Cornford M, Siegel JM (2000) Reduced number of hypocretin neurons in human narcolepsy. Neuron 27:469-474, doi:10.1016/50896-6273(00)00058-1

Thannickal TC, Lai Y-Y, Siegel JM (2007) Hypocretin (orexin) cell loss in Parkinson's disease. Brain 130:1586-1595, doi:10.1093/brain/awm097

Tohgi H, Abe T, Takahashi S, Kimura M, Takahashi J, Kikuchi T (1992) Concentrations of serotonin and its related substances in the cerebrospinal fluid in patients with Alzheimer type dementia. Neurosci Lett 141:9-12, doi:10.1016/0304-3940(92) 90322-X

Tohgi H, Abe T, Takahashi S, Takahashi J, Hamato H (1993) Concentrations of serotonin and its related substances in the cerebrospinal fluid of Parkinsonian patients and their relations to the severity of symptoms. Neurosci Lett 150:71-74, doi:10.1016/0304-3940(93)90111-W

Tsunematsu T, Kilduff TS, Boyden ES, Takahashi S, Tominaga M, Yamanaka A (2011) Acute optogenetic silencing of orexin/hypocretin neurons induces slow-wave sleep in mice. J Neurosci 31:10529-10539, doi:10.1523/JNEUROSCI.0784-11.2011

Turner MR, Rabiner EA, Hammers A, Al-Chalabi A, Grasby PM, Shaw CE, Brooks DJ, Leigh PN (2005) [11C]-WAY100635 PET demonstrates marked 5-HT1A receptor changes in sporadic ALS. Brain 128:896-905, doi:10.1093/brain/awh428

Uchida S, Hotta H, Misawa H, Kawashima K (2013) The missing link between longterm stimulation of nicotinic receptors and the increases of acetylcholine release and vasodilation in the cerebral cortex of aged rats. J Physiol Sci 63:95-101, doi:10.1007/s12576-012-0239-2

Uehara T, Nakamura T, Yao D, Shi ZQ, Gu Z, Ma Y, Masliah E, Nomura Y, Lipton SA (2006) S-nitrosylated protein-disulphide isomerase links protein misfolding to neurodegeneration. Nature 441:513-517, doi:10.1038/nature04782

Valko PO, Gavrilov W, Yamamoto M, Reddy H, Haybaeck J, Mignot E, Baumann CR, Scammell TE (2013) Increase of histaminergic tuberomammillary neurons in narcolepsy. Ann Neurol 74:794-804, doi:10.1002/ana.24019

Van Luijtelaar MGPA, Steinbusch HWM, Tonnaer JADM (1988) Aberrant morphology of serotonergic fibers in the forebrain of the aged rat. Neurosci Lett 95:93-96, doi:10.1016/0304-3940(88)90638-6

Van Luijtelaar MGPA, Tonnaer JADM, Steinbusch HWM (1992) Aging of the serotonergic system in the rat forebrain: an immunocytochemical and neurochemical study. Neurobiol Aging 13:201-215, doi:10.1016/0197-4580 (92) $90032-S$

Vitiello MV, Bliwise DL, Prinz PN (1992) Sleep in Alzheimer's disease and the sundown syndrome. Neurology 42:83-93, discussion 93-4

Von Coelln R, Thomas B, Savitt JM, Lim KL, Sasaki M, Hess EJ, Dawson VL, Dawson TM (2004) Loss of locus coeruleus neurons and reduced startle in parkin null mice. Proc Natl Acad Sci U S A 101:10744-10749, doi:10.1073/pnas.0401297101

Wade AG, Farmer M, Harari G, Fund N, Laudon M, Nir T, Frydman-Marom A, Zisapel N (2014) Add-on prolonged-release melatonin for cognitive function and sleep in mild to moderate Alzheimer's disease: a 6-month, randomized, placebo-controlled, multicenter trial. Clin Interv Aging 9:947-961, doi:10.2147/CIA.S65625

Weishaupt JH, Bartels C, Pölking E, Dietrich J, Rohde G, Poeggeler B, Mertens N, Sperling S, Bohn M, Hüther G, Schneider A, Bach A, Sirén AL, Hardeland R, Bähr M, Nave KA, Ehrenreich H (2006) Reduced oxidative damage in ALS by high-dose enteral melatonin treatment. J Pineal Res 41:313-323, doi:10.1111/ j.1600-079X.2006.00377.x

Wennberg AM, Canham SL, Smith MT, Spira AP (2013) Optimizing sleep in older adults: treating insomnia. Maturitas 76:247-252, doi:10.1016/j. maturitas.2013.05.007

Wennström M, Londos E, Minthon L, Nielsen HM (2012) Altered CSF orexin and a-synuclein levels in dementia patients. J Alzheimers Dis 29:125-132, doi:10.3233/JAD-2012-111655

Wilson RS, Nag S, Boyle PA, Hizel LP, Yu L, Buchman AS, Schneider JA, Bennett DA (2013) Neural reserve, neuronal density in the locus ceruleus, and cognitive decline. Neurology 80:1202-1208, doi:10.1212/ WNL.0b013e3182897103
Wolf D, Grothe M, Fischer FU, Heinsen H, Kilimann I, Teipel S, Fellgiebel A (2014) Association of basal forebrain volumes and cognition in normal aging. Neuropsychologia 53:54-63, doi:10.1016/j.neuropsychologia.2013.11.002

Xie L, Kang H, Xu Q, Chen MJ, Liao Y, Thiyagarajan M, O'Donnell J, Christensen DJ, Nicholson C, Iliff JJ, Takano T, Deane R, Nedergaard M (2013) Sleep drives metabolite clearance from the adult brain. Science 342:373-377, doi:10.1126/ science. 1241224

Xu A, Sakurai E, Kuramasu A, Zhang J, Li J, Okamura N, Zhang D, Yoshikawa T, Watanabe T, Yanai K (2010) Roles of hypothalamic subgroup histamine and orexin neurons on behavioral responses to sleep deprivation induced by the treadmill method in adolescent rats. J Pharmacol Sci 114:444-453

Yanai K, Watanabe T, Meguro K, Yokoyama H, Sato I, Sasano H, Itoh M, Iwata R, Takahashi T, Ido T (1992) Age-dependent decrease in histamine $\mathrm{H} 1$ receptor in human brains revealed by PET. Neuroreport 3:433-436

Yang Y, Schmitt HP (2001) Frontotemporal dementia: evidence for impairment of ascending serotoninergic but not noradrenergic innervation. Immunocytochemical and quantitative study using a graph method. Acta Neuropathol 101:256-270

Zarow C, Lyness SA, Mortimer JA, Chui HC (2003) Neuronal loss is greater in the locus coeruleus than nucleus basalis and substantia nigra in Alzheimer and Parkinson diseases. Arch Neurol 60:337-341

Zemek F, Drtinova L, Nepovimova E, Sepsova V, Korabecny J, Klimes J, Kuca K (2014) Outcomes of Alzheimer's disease therapy with acetylcholinesterase inhibitors and memantine. Expert Opin Drug Saf 13:759-774, doi:10.1517/ 14740338.2014.914168

Zhan G, Serrano F, Fenik P, Hsu R, Kong L, Pratico D, Klann E, Veasey SC (2005) $\mathrm{NADPH}$ oxidase mediates hypersomnolence and brain oxidative injury in a murine model of sleep apnea. Am J Respir Crit Care Med 172:921-929, doi:10.1164/rccm.200504-5810C

Zhang Y-Q, Mei J, Lü S-G, Zhao Z-Q (2002) Age-related alterations in responses of Nucleus basalis magnocellularis neurons to peripheral nociceptive stimuli. Brain Res 948:47-55, doi:10.1016/S0006-8993(02)02947-5

Zhang J-H, Sampogna S, Morales FR, Chase MH (2005) Age-related changes of hypocretin in basal forebrain of guinea pig. Peptides 26:2590-2596, doi:10.1016/j.peptides.2005.05.003

Zhang J, Zhu Y, Zhan G, Fenik P, Panossian L, Wang MM, Reid S, Lai D, Davis JG, Baur JA, Veasey $S$ (2014) Extended wakefulness: compromised metabolics in and degeneration of locus ceruleus neurons. J Neurosci 34:4418-4431, doi:10.1523/JNEUROSCI.5025-12.2014

Zhu M-Y, Wang W-P, lyo AH, Ordway GA, Kim KS (2005) Age-associated changes in mRNA levels of Phox2, norepinephrine transporter and dopamine betahydroxylase in the locus coeruleus and adrenal glands of rats. J Neurochem 94:828-838, doi:10.1111/j.1471-4159.2005.03245.X

Zhu Y, Fenik P, Zhan G, Mazza E, Kelz M, Aston-Jones G, Veasey SC (2007) Selective loss of catecholaminergic wake active neurons in a murine sleep apnea model. J Neurosci 27:10060-10071, doi:10.1523/JNEUROSCI.0857-07.2007

\section{Submit your manuscript to a SpringerOpen ${ }^{\odot}$ journal and benefit from:}

- Convenient online submission

- Rigorous peer review

- Immediate publication on acceptance

- Open access: articles freely available online

- High visibility within the field

- Retaining the copyright to your article

Submit your next manuscript at springeropen.com 